\title{
Utilization of different macroalgae by sea cucumber Apostichopus japonicus revealed by carbon stable isotope analysis
}

\author{
Bin Wen ${ }^{1,2}$, Qin-Feng Gao ${ }^{1,2, *}$, Shuang-Lin Dong ${ }^{1,2}$, Yi-Ran Hou ${ }^{1,2}$, Hai-Bo Yu ${ }^{1,2}$ \\ ${ }^{1}$ Key Laboratory of Mariculture, Ministry of Education, Ocean University of China, Qingdao, Shandong Province 266003, \\ PR China \\ ${ }^{2}$ Function Laboratory for Marine Fisheries Science and Food Production Processes, \\ Qingdao National Laboratory for Marine Science and Technology, Qingdao, Shandong Province 266003, PR China
}

\begin{abstract}
Understanding the feeding habit of sea cucumber Apostichopus japonicus (Selenka) is crucial for improving aquaculture techniques of this commercially important species. In the present study, carbon stable isotopes were used as trophic tracers to investigate the uptake of different macroalgae, including brown alga Sargassum muticum, red alga Gracilaria lemaneiformis and green alga Ulva lactuca by A. japonicus. A $70 \mathrm{~d}$ experiment was conducted to examine the carbon isotopic signatures of A. japonicus feeding on 6 different types of diets containing either pure powder of a single alga species or mixtures of 2 algae species. After the feeding trial, carbon isotope ratios $\left(\delta^{13} \mathrm{C}\right)$ of $A$. japonicus showed significant changes and reflected the isotopic compositions of corresponding diets. An isotope mixing model revealed the dietary preferences of $A$. japonicus between the 3 species of macroalgae, suggesting that green alga $U$. lactuca was the preferentially utilized food source of $A$. japonicus, followed by brown alga S. muticum. A. japonicus tended to reject red alga G. lemaneiformis in the presence of multiple macroalgae choices. Moreover, the specific growth rates of $A$. japonicus fed on S. muticum and U. lactuca were similar, but were both significantly higher than those fed on G. lemaneiformis, indicating the direct link between the feeding preferences and growth performance of $A$. japonicus.
\end{abstract}

KEY WORDS: Apostichopus japonicus $\cdot$ Macroalga $\cdot$ Stable isotope $\cdot$ Growth

\section{INTRODUCTION}

Sea cucumbers, belonging to the phylum Echinodermata and class Holothuroidea, are distributed worldwide in marine habitats, from shallow to deep seas. As deposit feeders, these organisms actively select organic-rich particles from the upper millimeters of sediments and promote bioturbation, thus playing an important role in detritus food chains (Yingst 1976, Uthicke 1999, Michio et al. 2003, Hudson et al. 2005, Slater \& Jeffs 2010, Slater et al. 2011). Moreover, in seagrass ecosystems, holothurians can

${ }^{*}$ Corresponding author: qfgao@ouc.edu.cn effectively accelerate the degradation of organic matter and enhance the transfer of seagrass-derived organic matter to sediments (Liu et al. 2013, Costa et al. 2014). Besides the ecological role in nutrient recycling, several sea cucumber species, including Apostichopus japonicus, are rich in a variety of bioactive compounds with nutritional and medicinal values (Aydın et al. 2011, Bordbar et al. 2011). In response increasing demand, an extensive trade in A. japonicus has developed and this species is widely cultured in northern China, Japan, Korea and Russia (Chen 2004, Toral-Granda et al. 2008). A better understand-

() The authors 2016. Open Access under Creative Commons by Attribution Licence. Use, distribution and reproduction are unrestricted. Authors and original publication must be credited. 
ing of the feeding ecology and physiology of $A$. japonicus will provide insights into the vital role they play in nutrient recycling in benthic environments and crucial information for improving the aquaculture techniques of this species (Uthicke 2001, Slater et al. 2011, Zamora \& Jeffs 2011).

Deposit-feeding A. japonicus ingest sedimentary organic matter, mainly composed of detritus from macroalgae to seagrass, decayed animals and other microorganisms such as benthic diatoms, bacteria and protozoa (Zhang et al. 1995). Previous studies have demonstrated that detritus derived from macroalgae is the major food source of A. japonicus (Sun et al. 2013). However, in eelgrass-rich meadows, decayed eelgrass debris such as Zostera marina can be an important food source for A. japonicus (Liu et al. 2013). Many other sea cucumber species including Stichopus chloronotus, S. tremulus and Mesothuria intestinalis also tend to select sediments containing high macroalgal biomass (Uthicke \& Karez 1999, Hudson et al. 2005). Different basal food resources, e.g. brown, red and green algae, generally have distinctive biochemical compositions and consequently different nutritional values and food quality, which could potentially influence the feeding selectivity of consumers (Danovaro et al. 2001, Adin \& Riera 2003, Jormalainen et al. 2005, Rodil et al. 2008, Duarte et al. 2010). Although the biology of A. japonicus has been studied for several decades, research efforts on the feeding habits and food preferences are relatively scarce to date (Gao et al. 2011, Sun et al. 2013).

Utilization of different food resources by aquatic animals can be directly assessed by stomach content analysis. However, this traditional approach is often destructive for larger animals and is not feasible for smaller organisms, particularly for A. japonicus or other aquatic invertebrates due to the small size and the digestive damage caused to the food particles (Galloway et al. 2015, Gao et al. 2011). More importantly, gut content analysis generally only provides a snapshot of recently ingested food and may be biased towards non-digestible food items (Bowen \& Iverson 2013, Galloway et al. 2015), thus making it difficult to distinguish the contributions of various potential food sources. More recently, stable isotope analysis of carbon and nitrogen has been used as a powerful tool to determine the food sources and feeding selectivity, trophic positions and movement patterns of both aquatic and terrestrial organisms (Peterson \& Fry 1987, Hobson 1999, Adin \& Riera 2003, Gao et al. 2006, Boecklen et al. 2011). Stable isotope analysis generally integrates diet information over an extended time period, typically weeks to months, depending on tissue-specific turnover rates (MacAvoy et al. 2001, Phillips \& Eldridge 2006, Logan \& Lutcavage 2010). Moreover, the development of mixing models allows us to estimate the relative contributions of potential resources to the consumer's food absorption (Phillips \& Koch 2002, Phillips \& Gregg 2003).

Simultaneous provision of various food resources is an effective way to examine the feeding selectivity of mobile sea cucumbers (Uthicke \& Karez 1999). In this study, 3 species of macroalgae, including brown alga Sargassum muticum, red alga Gracilaria lemaneiformis and green alga Ulva lactuca were mixed with each other as diets to feed A. japonicus. The objectives of the present study were to compare the food quality of the 3 macroalgal species and to quantify the relative contributions of different macroalgae to the food uptake of A. japonicas. The subsequent effects of food preferences on the growth performance of $A$. japonicus were evaluated to provide scientific evidence for optimizing the ingredients of artificial feed used in A. japonicus farming.

\section{MATERIALS AND METHODS}

\section{Experimental diets}

Three macroalgal species, including brown alga Sargassum muticum, red alga Gracilaria lemaneiformis and green alga Ulva lactuca were used as feed ingredients in the experiment. Dried macroalgae were obtained from Qingdao Great Seven Biotech. Six types of diets were prepared for Apostichopus japonicus (Selenka) containing the ingredient of either pure powder of a single alga species or mixtures of 2 algae species, i.e. single $S$. muticum (S), G. lemaneiformis $(\mathrm{G})$ and $U$. lactuca $(\mathrm{U})$, and mixtures (1:1) of $S$. muticum and G. lemaneiformis (SG), $S$. muticum and U. lactuca (SU), and G. lemaneiformis and $U$. lactuca (GU). The macroalgae were ground into fine powder through a $150 \mu \mathrm{m}$ mesh, then well mixed before being pelletized with a feed processing machine and stored at $4^{\circ} \mathrm{C}$ for future use.

\section{Experiment and sample collection}

The experiment was conducted at the laboratory of Qingdao National Ocean Scientific Research Center, Ocean University of China. A. japonicus juveniles were collected from a local sea cucumber farm and acclimatized for $14 \mathrm{~d}$ before the start of the experi- 
ment. After $48 \mathrm{~h}$ starvation, a total of 108 juvenile $A$. japonicus with initial body weights of $5.57 \pm 0.11 \mathrm{~g}$ were randomly distributed into 18 glass aquaria $(50 \times$ $40 \times 40 \mathrm{~cm}$ ) in each of which 6 individuals were cultured. The 18 aquaria were further divided into 6 groups with 3 replicates for each group. A. japonicus individuals in each of the 6 groups were fed with one of the 6 diets as described above. Prior to the experiment, 10 additional specimens were stored at $-80^{\circ} \mathrm{C}$ for the initial carbon stable isotope analysis.

During the following $70 \mathrm{~d}$ feeding experiment, the A. japonicus were fed once a day at 15:00 $\mathrm{h}$ with a daily ration of $5 \%$ body weight. Water temperature was maintained at $16.5 \pm 0.5^{\circ} \mathrm{C}$, salinity ranged from 29 to 31 , aeration was provided continuously, dissolved oxygen was $>6.0 \mathrm{mg} \mathrm{l}^{-1}$. Two-thirds of the volume of the water in each aquarium was exchanged with filtered seawater daily. Uneaten feed residue and feces were collected by siphoning during water exchange.

At the end of the experiment, A. japonicus individuals in each aquarium were starved for $48 \mathrm{~h}$ to empty the gut content, then weighed to the nearest $0.01 \mathrm{~g}$ and dissected. Samples of body wall tissues were kept at $-80^{\circ} \mathrm{C}$ for further analysis.

\section{$\mathrm{C} / \mathrm{N}$ and carbon stable isotope ratios}

Carbon and nitrogen contents of the 3 macroalgal species were measured using an elemental analyzer (Elementar Vario ELIII) and molar ratio of carbon to nitrogen (C/N ratio) was calculated. Samples of collected body tissues were dried at $60^{\circ} \mathrm{C}$ for $48 \mathrm{~h}$ to constant weight and ground into a fine powder for carbon stable isotope measurements. Carbon stable isotope ratios of body tissues and algal powder were determined using an elemental analyzer coupled with an isotope ratio mass spectrometer (EA-IRMS, ThermoFinnigan MAT Delta Plus). A laboratory working standard (glycine) was run for every 10 samples. Analytical precision was $\pm 0.1 \%$.

\section{Stable isotope mixing model and statistical analysis}

Results of carbon isotope ratios were expressed in standard $\delta$-unit notation, which is defined as:

$$
\delta^{13} \mathrm{C}=\left[\left(R_{\text {sample }} / R_{\text {standard }}\right)-1\right] \times 1000 \%
$$

where $R$ is the ${ }^{13} \mathrm{C} /{ }^{12} \mathrm{C}$ ratio. The values were reported relative to the Vienna Pee Dee Belemnite (PDB) standard.
For diet groups SG, SU and GU, a 2-source concentration-weighted isotope mixing model was used to evaluate the contribution of each algal ingredient to the food uptake of A. japonicus (Phillips \& Koch 2002):

$\left(\delta^{13} C^{\prime}{ }_{X}-\delta^{13} C_{M}\right)[C]_{X} f_{X, B}+\left(\delta^{13} C^{\prime}{ }_{Y}-\delta^{13} C_{M}\right)[C]_{Y} f_{Y, B}=0$

where $f_{\mathrm{X}, \mathrm{B}}$ and $f_{\mathrm{Y}, \mathrm{B}}$ represent the fractions of assimilated biomass (B) of sources $\mathrm{X}, \mathrm{Y}$, respectively, in the mixture $\mathrm{M}$, therefore $f_{\mathrm{X}, \mathrm{B}}+f_{\mathrm{Y}, \mathrm{B}}=1$. $[\mathrm{C}]_{\mathrm{X}}$ and $[\mathrm{C}]_{\mathrm{Y}}$ represent the carbon concentrations in food sources $\mathrm{X}$, $\mathrm{Y}$, respectively. Isotopic signatures for the sources were corrected for trophic fractionation as designated by the prime symbol ('). Average fractionation effects of $1 \%$ for carbon isotope were used to correct stable isotope shifts for each trophic level (Peterson \& Fry 1987, Sun et al. 2013).

The growth performance of $A$. japonicus in each aquarium in terms of specific growth rate (SGR) was calculated as:

$$
\operatorname{SGR}\left(\% \mathrm{~d}^{-1}\right)=\left(\ln W_{\mathrm{f}}-\ln W_{\mathrm{i}}\right) / t \times 100
$$

where $W_{\mathrm{f}}$ and $W_{\mathrm{i}}$ are the final and initial wet body weights, respectively, of $A$. japonicus, and $t$ is the duration of the experiment in days.

The differences in $\mathrm{C} / \mathrm{N}$ ratios and $\delta^{13} \mathrm{C}$ values between the 3 algal species and $\delta^{13} \mathrm{C}$ values and growth performance of $A$. japonicus between the 6 diet groups were compared with 1-way ANOVA followed by Tukey's post hoc test for multiple comparisons at a significance level of $0.05(p<0.05)$. Prior to statistical analyses, raw data were diagnosed for normality of distribution and homogeneity of variance with the Kolmogorov-Smirnov test and Levene's test, respectively. The statistical analyses were performed using SPSS software for Windows (Release 20.0).

\section{RESULTS}

\section{Carbon stable isotope and $\mathrm{C} / \mathrm{N}$ ratios of macroalgae}

Carbon stable isotope ratios and $\mathrm{C} / \mathrm{N}$ ratios of the 3 macroalgae ingredients including brown alga Sargassum muticum, red alga Gracilaria lemaneiformis and green alga Ulva lactuca are presented in Table 1. Significant differences in the $\delta^{13} \mathrm{C}$ values and $\mathrm{C} / \mathrm{N}$ ratios between the 3 ingredients were observed (ANOVA, $\mathrm{p}<0.05$ ). U. lactuca had the highest $\delta^{13} \mathrm{C}$ values $(-13.50 \%)$, followed by $S$. muticum $(-16.06 \%)$, while $G$. lemaneiformis exhibited the lowest values $(-20.06 \%)$. U. lactuca showed the lowest $\mathrm{C} / \mathrm{N}$ ratios 
Table 1. Carbon stable isotope ratios $\left(\delta^{13} \mathrm{C}\right), \mathrm{C}$ and $\mathrm{N}$ contents, and $\mathrm{C} / \mathrm{N}$ ratios of macroalgae used as dietary ingredients in a study of the feeding habit of sea cucumber Apostichopus japonicus. Data are presented as mean $\pm \mathrm{SD}(\mathrm{n}=3)$. Different letters within the same column indicate significant differences (ANOVA, $\mathrm{p}<0.05$ )

\begin{tabular}{|lcccc|}
\hline Ingredient & $\delta^{13} \mathrm{C}(\%)$ & C content $(\%)$ & N content $(\%)$ & C/N \\
\hline Sargassum muticum & $-16.06 \pm 0.17^{\mathrm{b}}$ & $26.50 \pm 1.08^{\mathrm{b}}$ & $2.94 \pm 0.24^{\mathrm{b}}$ & $9.04 \pm 0.42^{\mathrm{ab}}$ \\
Gracilaria lemaneiformis & $-20.06 \pm 0.22^{\mathrm{c}}$ & $23.61 \pm 2.04^{\mathrm{b}}$ & $2.56 \pm 0.11^{\mathrm{b}}$ & $9.22 \pm 0.40^{\mathrm{b}}$ \\
Ulva lactuca & $-13.50 \pm 0.08^{\mathrm{a}}$ & $14.15 \pm 0.73^{\mathrm{a}}$ & $1.69 \pm 0.08^{\mathrm{a}}$ & $8.36 \pm 0.08^{\mathrm{a}}$ \\
\hline
\end{tabular}

(8.36), followed by S. muticum (9.04), while $G$. lemaneiformis exhibited the highest $\mathrm{C} / \mathrm{N}$ ratios (9.22).

\section{Carbon stable isotope ratios of Apostichopus japonicus}

Initial and final carbon stable isotope ratios in different diet groups of $A$. japonicus are shown in Fig. 1. After the $70 \mathrm{~d}$ feeding trial, remarkable changes occurred in the $\delta^{13} \mathrm{C}$ values of $A$. japonicus relative to the initial values, particularly those in the diet groups U and SU (ANOVA, p < 0.05), and appeared to reflect the isotopic compositions of corresponding diets. For the single algae groups, due to the uptake of relatively isotopically heavy $S$. muticum and U. lactuca, the average $\delta^{13} \mathrm{C}$ values of $A$. japonicus in the diet groups $\mathrm{S}$ and $U(-15.49 \pm 0.14$ and $-14.42 \pm 0.05 \%$, respectively [mean $\pm \mathrm{SD}$ ]) were significantly enriched compared to the initial $\delta^{13} \mathrm{C}$ values $(-17.48 \pm$

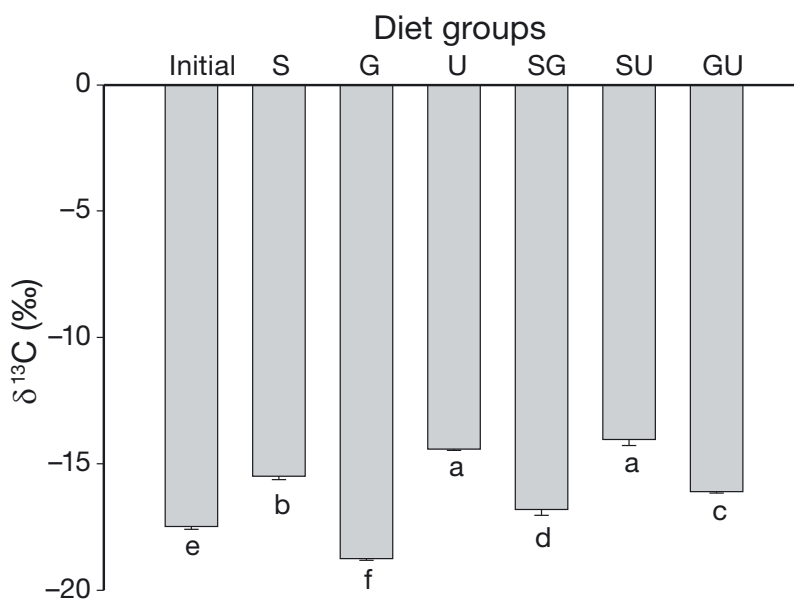

Fig. 1. Carbon stable isotope ratios $\left(\delta^{13} \mathrm{C}\right)$ of sea cucumber Apostichopus japonicus at the beginning of the experiment (initial) and at the end of the experiment after feeding on different diets. S: a diet of Sargassum muticum; G: Gracilaria lemaneiformis; U: Ulva lactuca; S: a mixture of $S$. muticum and G. lemaneiformis; SU: S. muticum and U. lactuca; GU: G. lemaneiformis and U. lactuca. Error bars represent $1 \mathrm{SD}(\mathrm{n}=3)$. Values with different letters represent significant differences $(\mathrm{p}<0.05)$
$0.11 \%$ ) (ANOVA, p < 0.05). By contrast, A. japonicus in diet group $\mathrm{G}$ exhibited the most ${ }^{13} \mathrm{C}$-depleted values $(-18.75 \pm 0.07 \%$ ) among the 6 diet groups due to the assimilation of isotopically light $G$. lemaneiformis. Moreover, the average $\delta^{13} \mathrm{C}$ value of $-18.75 \%$ for the A. japonicus in the diet group $\mathrm{G}$ was very near to that of the G. lemaneiformis (-20.06\%) after the correction of $1 \%$ carbon isotope fractionation for each trophic level.

As for the mixed diet groups, the mean $\delta^{13} \mathrm{C}$ values of A. japonicus in the diet groups SG, SU and GU $(-16.81 \pm 0.23,-14.04 \pm 0.24$ and $-16.10 \pm 0.06 \%$, respectively) were all located within those of the 2 corresponding macroalgal ingredients after correction of isotope fractionation, indicating the simultaneous absorption of 2 algae species by $A$. japonicus. In particular, $A$. japonicus in the diet group SU showed the most enriched $\delta^{13} \mathrm{C}$ values $(-14.04 \%$ ) among the 6 diet groups as a result of the higher contribution of $U$. lactuca, compared with that of $S$. muticum, to the food assimilation of A. japonicus.

\section{Food contributions of different macroalgae}

At the end of the experiment, the 2-source concentration-weighted dual isotope mixing model revealed that the proportional contribution of $S$. muticum $(53.50 \pm 5.99 \%)$ to the diet of $A$. japonicus was higher than that of $G$. lemaneiformis $(46.50 \pm 5.99 \%)$ in the diet group SG. However, in the diet group SU, the mean contribution of $S$. muticum (44.91 $\pm 9.97 \%$ ) was lower relative to that of $U$. lactuca $(55.09 \pm 9.97 \%)$. Similarly, the proportional contribution of $G$. lemaneiformis (42.26 $\pm 0.83 \%)$ was lower compared with that of U. lactuca $(57.74 \pm 0.83 \%)$ in the diet group GU.

\section{Growth of Apostichopus japonicus}

Initial and final body wet weights of A. japonicus in different diet groups are shown in Table 2. At the beginning of the experiment, there were no signifi- 
Table 2. Initial and final body wet weight of Apostichopus japonicus in different diet groups. Data are mean $\pm \mathrm{SD}(\mathrm{n}=3)$. Different letters in same row represent significant differences between diets at the significance level of $0.05(\mathrm{p}<0.05)$. See Fig. 1 legend for descriptions of diets

\begin{tabular}{|lcc|}
\hline $\begin{array}{l}\text { Diet } \\
\text { group }\end{array}$ & \multicolumn{2}{c|}{$\begin{array}{l}\text { Wet weight }\left(\text { ind }^{-1}\right) \\
\text { Initial }\end{array}$} \\
\hline & & Final \\
S & $5.57 \pm 0.16$ & $15.45 \pm 1.68^{\mathrm{c}}$ \\
G & $5.62 \pm 0.10$ & $10.98 \pm 0.74^{\mathrm{ab}}$ \\
U & $5.52 \pm 0.21$ & $14.91 \pm 0.90^{\mathrm{c}}$ \\
SG & $5.60 \pm 0.05$ & $15.21 \pm 1.37^{\mathrm{c}}$ \\
SU & $5.49 \pm 0.02$ & $10.22 \pm 1.21^{\mathrm{a}}$ \\
GU & $5.61 \pm 0.11$ & $14.04 \pm 0.87^{\mathrm{bc}}$ \\
\hline
\end{tabular}

cant differences in the wet body weights of A. japonicus between the 6 diet groups (ANOVA, $\mathrm{p}>0.05$ ). After the $70 \mathrm{~d}$ feeding trial, the final body weight of A. japonicus in the diet group SU was significantly lower than in other diet groups $(\mathrm{p}<0.05)$. Final body weight of A. japonicus in diet group G was significantly lower than in the diet groups $\mathrm{S}$ and $\mathrm{U}(\mathrm{p}<0.05)$ and no significant differences were observed between the diet groups $\mathrm{S}$ and $\mathrm{U}(\mathrm{p}>0.05)$. Correspondingly, the SGR of A. japonicus in the diet groups $\mathrm{G}$ and $\mathrm{SU}$ were significantly lower than those in the other diet groups $(\mathrm{p}<0.05)$. There were no significant differences in SGR values between the diet groups $\mathrm{S}$ and $\mathrm{U}(\mathrm{p}>0.05)$ (Fig. 2).

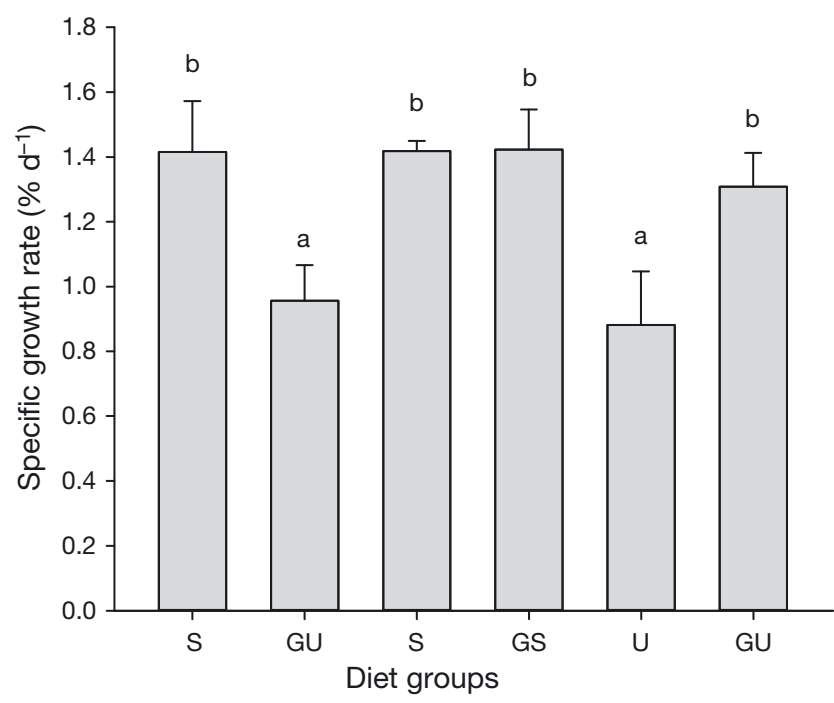

Fig. 2. Specific growth rates of Apostichopus japonicus in different diet groups. Error bars represent 1 SD $(n=3)$. Values with different letters represent significant difference at the significance level of 0.05 ( $p<0.05)$. See Fig. 1 legend for descriptions of diets

\section{DISCUSSION}

Stable isotope analysis, which is based on the predictable trophic enrichment between the isotopic signatures of consumers and their diets, is increasingly being used to investigate the feeding patterns and trophic positions of animals in food webs (Post 2002, Boecklen et al. 2011). Carbon isotope ratios $\left(\delta^{13} \mathrm{C}\right)$ generally maintain a close similarity between consumers and their diets with $1 \%$ of fractionation effects and are commonly used to trace the food sources and feeding selectivity of animals (Fleming et al. 1993, Sauriau \& Kang 2000). By contrast, nitrogen stable isotopes are frequently used to determine the trophic positions of various species in food webs, since $\delta^{15} \mathrm{~N}$ is more enriched than $\delta^{13} \mathrm{C}$ (by a mean of $\sim 3.4 \%$ ) between each trophic level (Post 2002, McCutchan et al. 2003). In the previous studies, food sources and dietary preferences of $A$. japonicus were successfully determined using single carbon stable isotopes (Gao et al. 2011, Yu et al. 2015). Therefore, nitrogen stable isotopes were not applied in the present experiment.

Applications of stable isotope analysis depend on the distinct differences in the isotopic signatures of various food resources (Peterson \& Fry 1987). In the present study, there were significant differences in $\delta^{13} \mathrm{C}$ values between brown alga Sargassum muticum, red alga Gracilaria lemaneiformis and green alga Ulva lactuca. This variation reflected taxonomic differences, probably due to the differences in the mechanisms adopted by the primary producers for use of $\mathrm{CO}_{2}$ and $\mathrm{HCO}_{3}{ }^{-}$for photosynthesis, and their abilities in this regard (Maberly et al. 1992, Michener \& Lajtha 2008, Mendonça et al. 2013), as well as the site-specific physicochemistry and biogeochemistry, particularly with regard to concentrations of dissolved inorganic carbon and flow rates (Finlay et al. 2002, Graham et al. 2014). Accordingly, such distinct isotopic signatures provided an opportunity to infer the dietary preferences of $A$. japonicus for the 3 macroalgal species using carbon stables isotope as trophic tracers.

Previous studies have shown that the half-life of carbon isotopic turnover in the body tissue of $A$. japonicus $(5.14 \pm 0.17 \mathrm{~g})$ is $21.39 \mathrm{~d}$ (Sun et al. 2012). In the present experiment, after the $70 \mathrm{~d}$ feeding trial, A. japonicus with similar sizes $(5.57 \pm 0.11 \mathrm{~g})$ showed substantial growth and could complete their isotopic turnover after diet switch as a result of growth and metabolic turnover of existing tissues (Phillips \& Eldridge 2006, Sun et al. 2012, Xia et al. 2015). For A. japonicus in the single algae diet groups, shifts in 
$\delta^{13} \mathrm{C}$ values towards those of corresponding macroalgae after isotopic fractionation correction were pronounced, suggesting the assimilation of $S$. muticum, G. lemaneiformis and U. lactuca by A. japonicus in the diet groups $\mathrm{S}, \mathrm{G}$ and $\mathrm{U}$, respectively.

Analyses of carbon stable isotopes of $A$. japonicus in the mixed diet groups revealed the relative contributions of different macroalgae to the food sources of $A$. japonicus. For diet groups $\mathrm{SG}$ and $\mathrm{GU}$, the 2 -source mixing models indicated that the proportional contributions of $S$. muticum and U. lactuca were obviously higher than that of G. lemaneiformis, suggesting that the assimilation of $G$. lemaneiformis was partially replaced by $S$. muticum and $U$. lactuca in these 2 diet groups, respectively, while for diet group SU, the contribution of $S$. muticum was lower relative to that of $U$. lactuca, indicating the relatively higher importance of $U$. lactuca than $S$. muticum as a food source of $A$. japonicus. These results revealed the selective assimilation of different macroalgae by A. japonicus. It appeared that $A$. japonicus preferentially utilized U. lactuca, followed by $S$. muticum, and tended to reject $G$. lemaneiformis in the presence of multiple macroalgal species. Such results are consistent with the study by Gao et al. (2011) in which $A$. japonicus showed obvious preferences for brown alga Sargassum thunbergii relative to G. lemaneiformis. Similarly, Yingst (1976) reported that detritus derived from the red algae were not readily assimilated by the epibenthic deposit-feeding holothurian Parastichopus parvimensis.

The selective utilization among various basal food resources can be attributed to nutritional quality and the potential availability of different food sources (Boettcher \& Targett 1993, Jormalainen et al. 2005, Rodil et al. 2008, Duarte et al. 2010, Seymour et al. 2013). In the present study, U. lactuca had lower $\mathrm{C} / \mathrm{N}$ ratios compared with $S$. muticum or G. lemaneiformis, indicating the relatively high food availability of $U$. lactuca for A. japonicus, as organic nitrogen is more readily utilized than organic carbon (Danovaro et al. 2001). A. japonicus tended to reject G. lemaneiformis, probably due to the higher $\mathrm{C} / \mathrm{N}$ ratios and subsequent lower digestibility of this species relative to $U$. lactuca and $S$. muticum. Similarly, S. muticum might contain a high content of low digestible refractory compounds, such as phlorotannins, which could potentially reduce the assimilation efficiencies of $A$. japonicus (Boettcher \& Targett 1993, Jormalainen et al. 2005).

As a consequence of the relatively low preference for $G$. lemaneiformis, A. japonicus in the diet group G showed the lower SGR compared with those in the diet groups $\mathrm{S}$ or $\mathrm{U}$, suggesting the direct link between the feeding preferences and their growth performance. On the other hand, A. japonicus in the mixed diet groups SG and GU achieved a SGR comparable with those in the diet groups $\mathrm{S}$ and $\mathrm{U}$ and significantly higher SGR than those in the diet group G probably because the tender nature of $S$. thunbergii or $U$. lactuca might, to some extent, enhance the digestibility of $G$. lemaneiformis in the diet groups SG and GU, respectively. Such findings are consistent with the results of the study on the growth performance of another echinoderm species sea urchin Tripneustes gratilla, where the addition of brown algae in red algae improved the growth of this species (Seymour et al. 2013).

In conclusion, results of the present study revealed the feeding preference of $A$. japonicus between different macroalgal species. U. lactuca was most preferentially utilized as a food source by A. japonicus, followed by $S$. muticum. A. japonicus tended to reject $G$. lemaneiformis in the presence of multiple macroalgal species. As a result of the preference and selectivity with respect to different food sources, A. japonicus showed significant differences in growth performance under various feeding regimes. On the other hand, the feeding selectivity of benthic organisms such as A. japonicus might result in substantial changes in ecological conditions. By means of chemically altering (e.g. digesting) and physically redistributing macroalgal detritus in sediments, these organisms are likely to dramatically affect the structure, function and energy flow of benthic ecosystems (Miller et al. 2000, Fornes et al. 2001, Ginger et al. 2001).

Acknowledgements. This study was funded by the National Natural Science Foundation of China (Grant Nos. 31172426 $\& 31372549$ ) and the Ministry of Science and Technology of China (Grant No. 2011BAD13B03).

\section{LITERATURE CITED}

Adin R, Riera P (2003) Preferential food source utilization among stranded macroalgae by Talitrus saltator (Amphipod, Talitridae): a stable isotopes study in the northern coast of Brittany (France). Estuar Coast Shelf Sci 56: 91-98

Aydın M, Sevgili H, Tufan B, Emre Y, Köse S (2011) Proximate composition and fatty acid profile of three different fresh and dried commercial sea cucumbers from Turkey. Int J Food Sci Technol 46:500-508

Boecklen WJ, Yarnes CT, Cook BA, James AC (2011) On the use of stable isotopes in trophic ecology. Annu Rev Ecol Evol Syst 42:411-440

$>$ Boettcher AA, Targett NM (1993) Role of polyphenolic molecular size in reduction of assimilation efficiency in Xiphister mucosus. Ecology 74:891-903 
Bordbar S, Anwar F, Saari N (2011) High-value components and bioactives from sea cucumbers for functional foods - a review. Mar Drugs 9:1761-1805

Bowen WD, Iverson SJ (2013) Methods of estimating marine mammal diets: a review of validation experiments and sources of bias and uncertainty. Mar Mamm Sci 29: $719-754$

Chen JX (2004) Present status and prospects of sea cucumber industry in China. In: Lovatelli A, Conand C, Purcell S, Uthicke S, Hamel JF, Mercier A (eds) Advances in sea cucumber aquaculture and management. Food and Agriculture Organization, Rome, p 25-38.

> Costa V, Mazzola A, Vizzini S (2014) Holothuria tubulosa Gmelin 1791 (Holothuroidea, Echinodermata) enhances organic matter recycling in Posidonia oceanica meadows. J Exp Mar Biol Ecol 461:226-232

> Danovaro R, Dell'Anno A, Fabiano M, Pusceddu A, Tselepides A (2001) Deep-sea ecosystem response to climate changes: the eastern Mediterranean case study. Trends Ecol Evol 16:505-510

> Duarte C, Navarro JM, Acuña K, Gómez I (2010) Feeding preferences of the sandhopper Orchestoidea tuberculata: the importance of algal traits. Hydrobiologia 651:291-303

Finlay JC, Khandwala S, Power MG (2002) Spatial scales of carbon floow in a river food web. Ecology 83:1845-1859

Fleming TH, Nuñez RA, Sternberg LSL (1993) Seasonal changes in the diets of migrant and non-migrant nectarivorous bats as revealed by carbon stable isotope analysis. Oecologia 94:72-75

Fornes WL, DeMaster DJ, Smith CR (2001) A particle introduction experiment in Santa Catalina Basin sediments: testing the age-dependent mixing hypothesis. J Mar Res 59:97-112

Galloway AW, Brett MT, Holtgrieve GW, Ward EJ and others (2015) A fatty acid based Bayesian approach for inferring diet in aquatic consumers. PLoS One 10:e0129723

> Gao QF, Shin PKS, Lin GH, Chen SP, Cheung SG (2006) Stable isotope and fatty acid evidence for uptake of organic waste by green-lipped mussels Perna viridis in a polyculture fish farm system. Mar Ecol Prog Ser 317:273-283

> Gao QF, Wang Y, Dong S, Sun Z, Wang F (2011) Absorption of different food sources by sea cucumber Apostichopus japonicus (Selenka) (Echinodermata: Holothuroidea): evidence from carbon stable isotope. Aquaculture 319: 272-276

> Ginger ML, Billett DS, Mackenzie KL, Kiriakoulakis K and others (2001) Organic matter assimilation and selective feeding by holothurians in the deep sea: some observations and comments. Prog Oceanogr 50:407-421

$>$ Graham CT, Harrison SSC, Harrod C (2014) Differences in the contributions of dietary water to the hydrogen stable isotope ratios of cultured Atlantic salmon and Arctic charr tissues. Hydrobiologia 721:45-55

- Hobson KA (1999) Tracing origins and migration of wildlife using stable isotopes: a review. Oecologia 120:314-326

Hudson IR, Wigham BD, Solan M, Rosenberg R (2005) Feeding behaviour of deep-sea dwelling holothurians: inferences from a laboratory investigation of shallow fjordic species. J Mar Syst 57:201-218

> Jormalainen V, Honkanen T, Vesakoski O, Koivikko R (2005) Polar extracts of the brown alga Fucus vesiculosus (L.) reduce assimilation efficiency but do not deter the herbivorous isopod Idotea baltica (Pallas). J Exp Mar Biol Ecol 317:143-157
Liu X, Zhou Y, Yang H, Ru S (2013) Eelgrass detritus as a food source for the sea cucumber Apostichopus japonicus Selenka (Echinidermata: Holothuroidea) in coastal waters of North China: an experimental study in flowthrough systems. PLoS One 8:e58293

Logan JM, Lutcavage ME (2010) Stable isotope dynamics in elasmobranch fishes. Hydrobiologia 644:231-244

Maberly S, Raven J, Johnston A (1992) Discrimination between ${ }^{12} \mathrm{C}$ and ${ }^{13} \mathrm{C}$ by marine plants. Oecologia 91 : 481-492

MacAvoy SE, Macko SA, Garman GC (2001) Isotopic turnover in aquatic predators: quantifying the exploitation of migratory prey. Can J Fish Aquat Sci 58:923-932

McCutchan JH, Lewis WM, Kendall C, McGrath CC (2003) Variation in trophic shift for stable isotope ratios of carbon, nitrogen, and sulfur. Oikos 102:378-390

> Mendonça R, Kosten S, Lacerot G, Mazzeo N and others (2013) Bimodality in stable isotope composition facilitates the tracing of carbon transfer from macrophytes to higher trophic levels. Hydrobiologia 710:205-218

Michener R, Lajtha K (2008) Stable isotopes in ecology and environmental science. Blackwell, Oxford

> Michio K, Kengo K, Yasunori K, Hitoshi M, Takayuki Y, Hideaki Y, Hiroshi S (2003) Effects of deposit feeder Stichopus japonicus on algal bloom and organic matter contents of bottom sediments of the enclosed sea. Mar Pollut Bull 47:118-125

> Miller RJ, Smith CR, DeMaster DJ, Fornes WL (2000) Feeding selectivity and rapid particle processing by deepsea megafaunal deposit feeders: a ${ }^{234}$ Th tracer approach. J Mar Res 58:653-673

Peterson BJ, Fry B (1987) Stable isotopes in ecosystem studies. Annu Rev Ecol Syst 18:293-320

Phillips DL, Eldridge PM (2006) Estimating the timing of diet shifts using stable isotopes. Oecologia 147:195-203

Phillips DL, Gregg JW (2003) Source partitioning using stable isotopes: coping with too many sources. Oecologia 136:261-267

Phillips DL, Koch PL (2002) Incorporating concentration dependence in stable isotope mixing models. Oecologia 130:114-125

Post DM (2002) Using stable isotopes to estimate trophic position: models, methods, and assumptions. Ecology 83:703-718

> Rodil IF, Olabarria C, Lastra M, López J (2008) Differential effects of native and invasive algal wrack on macrofaunal assemblages inhabiting exposed sandy beaches. J Exp Mar Biol Ecol 358:1-13

Sauriau PG, Kang CK (2000) Stable isotope evidence of benthic microalgae-based growth and secondary production in the suspension feeder Cerastoderma edule (Mollusca, Bivalvia) in the Marennes-Oléron Bay. Hydrobiologia 440:317-329

Seymour S, Paul NA, Dworjanyn SA, de Nys R (2013) Feeding preference and performance in the tropical sea urchin Tripneustes gratilla. Aquaculture 400-401:6-13

Slater MJ, Jeffs AG (2010) Do benthic sediment characteristics explain the distribution of juveniles of the depositfeeding sea cucumber Australostichopus mollis? J Sea Res 64:241-249

Slater MJ, Jeffs AG, Sewell MA (2011) Organically selective movement and deposit-feeding in juvenile sea cucumber, Australostichopus mollis determined in situ and in the laboratory. J Exp Mar Biol Ecol 409:315-323

> Sun ZL, Gao QF, Dong SL, Shin PKS, Wang F (2012) Estima- 
tes of carbon turnover rates in the sea cucumber Apostichopus japonicus (Selenka) using stable isotope analysis: the role of metabolism and growth. Mar Ecol Prog Ser 457:101-112

Sun Z, Gao Q, Dong S, Shin PK, Wang F (2013) Seasonal changes in food uptake by the sea cucumber Apostichopus japonicus in a farm pond: evidence from $\mathrm{C}$ and $\mathrm{N}$ stable isotopes. J Ocean Univ 12:160-168

Toral-Granda V, Lovatelli A, Vasconcellos M (2008) Sea cucumbers: a global review of fisheries and trade. FAO Fisheries and Aquaculture Technical Paper 516, Food and Agriculture Organization, Rome

Uthicke S (1999) Sediment bioturbation and impact of feeding activity of Holothuria (Halodeima) atra and Stichopus chloronotus, two sediment feeding holothurians, at Lizard Island, Great Barrier Reef. Bull Mar Sci 64: $129-141$

Uthicke S (2001) Nutrient regeneration by abundant coral reef holothurians. J Exp Mar Biol Ecol 265:153-170

Uthicke S, Karez R (1999) Sediment patch selectivity in tropical sea cucumbers (Holothurioidea: Aspidochirotida) analysed with multiple choice experiments. J Exp Mar

Editorial responsibility: Symon Dworjanyn, Coffs Harbour, New South Wales, Australia
Biol Ecol 236:69-87

> Xia B, Wang J, Gao QF, Sun Y, Zhang L, Ma J, Liu X (2015) The nutritional contributions of dietary protein sources to tissue growth and metabolism of sea cucumber Apostichopus japonicus (Selenka): evidence from nitrogen stable isotope analysis. Aquaculture 435:237-244

> Yingst JY (1976) The utilization of organic matter in shallow marine sediments by an epibenthic deposit-feeding holothurian. J Exp Mar Biol Ecol 23:55-69

Yu HB, Gao QF, Dong SL, Wen B, Hou YR, Ning LG (2015) Utilization of corn meal and extruded soybean meal by sea cucumber Apostichopus japonicus (Selenka): insights from carbon stable isotope analysis. Aquaculture 435:106-110

Zamora LN, Jeffs AG (2011) Feeding, selection, digestion and absorption of the organic matter from mussel waste by juveniles of the deposit-feeding sea cucumber, Australostichopus mollis. Aquaculture 317:223-228

Zhang BL, Sun DY, Wu YQ (1995) Preliminary study on the feeding habit of Apostichopus japonicus in the rocky coast waters along Lingshan Island. Mark Sci 3:11-13 (in Chinese with English abstract)

Submitted: September 28, 2015; Accepted: February 8, 2016 Proofs received from author(s): March 19, 2016 